\title{
Analisis Koneksi Matematika Ditinjau dari Tipe Kepribadian Sanguinis, Koleris, Melankolis, dan Plegmatis
}

\author{
Dewi Anggreini' ${ }^{1}$, Eko Priyojadmiko², Dwi Setiana ${ }^{3}$ \\ 1 Program Studi Pendidikan Matematika, Universitas Bhinneka PGRI, Tulungagung, \\ Indonesia; dewi.angreini@stkippgritulungagung.ac.id \\ 2 Program Studi Pendidikan Matematika, Universitas Bhinneka PGRI, Tulungagung, \\ Indonesia; jadmiko.uinsuka@gmail.com \\ 3 Program Studi Pendidikan Matematika, Universitas Bhinneka PGRI, Tulungagung, \\ Indonesia; dwisetiana99@gmail.com
}

\begin{abstract}
Abstrak. Matematika merupakan mata pelajaran yang memiliki konsep saling berkaitan antara materi yang satu dengan lainnya. Pemahaman materi memerlukan kemampuan dasar koneksi matematika. Kendala siswa ketika diberikan masalah baru, siswa tidak mampu mengkoneksikan dengan materi sebelumnya. Ketidakmampuan siswa disebabkan kurangnya daya ingat materi sebelumnya dan kurangnya memperhatikan penjelasan guru di dalam kelas. Hal ini disebabkan adanya perbedaan kepribadian sehingga membuat siswa memiliki kemampuan koneksi matematika yang berbeda. Tujuan penelitian ini mendeskripsikan kemampuan koneksi matematika berdasarkan tipe kepribadian sanguinis, koleris, melankolis, dan plegmatis. Penelitian ini merupakan penelitian deskriptif kualitatif dalam bentuk studi kasus. Metode pengumpulan data menggunakan angket untuk mengetahui tipe kepribadian, soal tes koneksi matematika, dan wawancara. Hasil penelitian diambil dari 4 subjek dari masing-masing tipe kepribadian diperoleh bahwa, siswa sanguinis dan plegmatis memiliki kemampuan koneksi matematika yang dapat memenuhi 5 indikator. Siswa korelis dan melankolis memiliki kemampuan koneksi matematika yang mampu memenuhi 4 indikator. Penelitian ini bermanfaat dalam meningkatkan koneksi matematika siswa dan lebih mengetahui masing-masing tipe kepribadiannya. Siswa yang memahami tipe kepribadiannya mampu menghilangkan sifat-sifat negatif yang menghambat koneksi matematika.
\end{abstract}

Kata Kunci: koneksi matematika, tipe kepribadian

\begin{abstract}
Mathematics is a subject that has interrelated concepts between one material with another. Understanding the material requires the basic abilities of mathematical connections. When students are given new problems, students are not able to connect with the previous material. The inability of students is due to lack of memory of previous material and lack of attention to teacher explanations in class. This is due to personality differences that make students have different mathematical connection abilities. The purpose of this study is to describe the
\end{abstract}


ability of mathematical connections based on sanguinis, koleris, melancholy, and plegmatic personality types. This research is a qualitative descriptive study in the form of case studies. The data collection method uses a questionnaire to determine personality types, math connection test questions, and interviews. The results of the study were taken from 4 subjects based of each personality type, it was found that sanguinis and plegmatis students had mathematical connection skills that could meet 5 indicators. Correspondent and melancholy students have mathematical connection skills that are able to meet 4 indicators. This research is useful in improving students' mathematical connections and knowing more about each type of personality. Students who understand their personality types are able to eliminate negative traits that hamper mathematical connections.

Keywords: mathematical connection, personality type

\section{Pendahuluan}

Matematika merupakan mata pelajaran yang materi didalamnya saling berkaitan. Bruner menyatakan bahwa setiap konsep dalam matematika saling berkaitan dengan konsep yang lain (Kumalasari, dkk, 2013). Dalam memahami materi perlu adanya koneksi matematika yang menjadi dasar dalam menguasai konsep matematika. Kemampuan siswa dalam koneksi matematika akan didapat pemahaman matematika yang mendalam dan dapat bertahan lama dikarenakan mengetahui keterkaitan ide antar topik, serta melalui pengalaman dalam kehidupan sehari-hari (Prasetyo, dkk, 2017).

Permasalahan yang sering terjadi yaitu ketika siswa diberikan beberapa soal pertanyaan, dimana jawabannya memiliki saling keterkaitan dengan materi sebelumnya. Kebanyakan siswa tidak mampu mengingat materi sebelumnya yang harus digunakan untuk menyelesaikan permasalahan tersebut. Ketika materi tersebut diajarkan kembali siswa dapat mengingatnya. Pada dasarnya siswa mampu mengerjakan soal akan tetapi tidak mau berusaha mengingatnya. Hal tersebut dipengaruhi oleh sifat-sifat yang ada pada setiap kepribadian. Berdasarkan hasil wawancara yang dilakukan terhadap guru mata pelajaran matematika, ditemukan fakta bahwa ketidakmampuan siswa mengerjakan soal dikarenakan siswa kurang memperhatikan ketika guru sedang menjelaskan. Berdasarkan pendapat para pakar pendidikan matematika, permasalahan merupakan soal atau pertanyaan yang harus direspon dan dijawab, akan tetapi tidak seluruh soal pertanyaan akan menjadi sebuah permasalahan (Khamidah \& Suherman, 2016). 
Kemampuan koneksi matematika sangat dibutuhkan oleh siswa untuk bisa menjawab seluruh permasalahan didalam ilmu matematika. Kemampuan yang bagus dalam pemecahan permasalahan akan dimiliki apabila seorang siswa memiliki pandangan yang luas akan materi matematika (Pauji, 2018). Sifat hakiki seseorang yang tercermin pada sikap dan perbuatan yang unik yang membedakan dirinya dengan orang lain adalah pengertian dari kepribadian. Keunikan yang dimiliki sesorang tergantung pada tipe kepribadian (Widodo, 2015). Hippocrates dan Galenus membagi tipe kepribadian seseorang menjadi 4, yaitu cholericus (koleris), sanguinicus (sanguinis), melancholicus (melankolis), dan flagmaticus (phlegmatis), (Fitria \& Siswono, 2014). Tipe kepribadian akan memiliki karakter masing-masing dalam mengemukakan pemikiran matematika baik secara lisan maupun tulisan (Prasetyo, dkk, 2017).

Berdasarkan penelitian koneksi matematika yang pernah dilakukan oleh peneliti sebelumnya yaitu Sholekah, dkk., (2017) yang membahas mengenai analisis kesulitan siswa menyelesaikan permasalahan matematika ditinjau dari koneksi matematis. Hasil penelitiannya adalah subjek yang memiliki tingkat koneksi matematis tinggi cenderung tidak memiliki kesulitan dalam menyelesaikan soal. Pada tingkat koneksi matematis sedang, siswa cenderung mengalami kesulitan pada penerapan prinsip dan menyelesaikan masalah verbal. Pada tingkat kemampuan koneksi matematis rendah siswa cenderung mengalami kesulitan dalam menyelesaikan soal limit fungsi yaitu pada pemahaman konsep, penerapan prinsip dan masalah verbal. Dari hasil penelitian tersebut peneliti melakukan penelitian mengenai koneksi matematika ditinjau dari tipe kepribadian. Pitriyani, dkk, (2018) membahas mengenai analisis kemampuan koneksi matematik siswa ditinjau dari kepercayaan diri. Hasil penelitiannya adalah kemampuan koneksi matematik siswa ditinjau dari self confidence masih sangat rendah. Dari penelitian sebelumnya maka peneliti meninjau kembali koneksi matematika berdasarkan tipe kepribadian kepribadian sanguinis, korelis, melankolis, dan plegmatis. Fitria dan Siswono (2014) meneliti tentang profil kemampuan berpikir kreatif dalam memecahkan masalah berdasarkan tipe kepribadian. Hasil penelitian tersebut menunjukan bahwa setiap tipe kepribadian memiliki ketrampilan berpikir kreatif yang berbeda-beda dalam memecahkan masalah. Kebaruan penelitian ini adalah peneliti melakukan penelitian tentang koneksi matematika siswa ditinjau dari tipe kepribadian korelis, sanguinis, melankolis, dan plegmatis dimana penelitian sebelumnya 
belum ada yang mengkaitkan 4 tipe kepribadian tersebut dengan koneksi matematika.

Penelitian ini bertujuan untuk mendeskripsikan kemampuan koneksi matematika siswa ditinjau dari tipe kepribadian korelis, sanguinis, melankolis, dan plegmatis.

Koneksi matematika merupakan kemampuan subjek dalam menggunakan pemikiran-pemikiran dalam matematika serta mengaplikasikan pemikiran tersebut dalam konteks diluar matematika (Romli, 2017). Latipah dan Afriansyah (2018) menjelaskan koneksi adalah kemampuan untuk menghubungkan sebuah ilmu dalam kehidupan sehari-hari, kemampuan berkoneksi harus dikuasai oleh siswa dikarenakan akan mempermudah siswa menyelesaikan soal berkaitan dengan kehidupan sehari-hari.

Satu materi didalam matematika merupakan sebuah prasyarat bagi materi yang lain. Konsep yang satu dapat menjelaskan konsep lainnya. Maka dari hal ini diperlukan kemampuan koneksi antar konsep dan materi dalam pembelajaran yang disebut sebagai kemampuan koneksi matematika (Sholekah, dkk, 2017). Dengan adanya koneksi matematika, kemampuan siswa akan bertambah luas dan semakin handal dalam memecahkan permasalahan serta pengambilan keputusan yang mendalam, masuk akal dan dapat dipertanggungjawabkan berdasarkan pemikiran yang cerdas. (Hartanti, 2016).

Berdasarkan uraian tersebut maka bisa diambil kesimpulan, koneksi matematika merupakan sebuah kemampuan ilmu matematika terhadap ilmu matematika itu sendiri ataupun dengan ilmu diluar matematika. Penelitian ini menggunakan indikator menurut Romli (2018) yang bisa dilihat pada tabel berikut:

Tabel 1. Aspek dan Indikator Teknis Koneksi Matematika

\begin{tabular}{|c|c|}
\hline Aspek & Indikator Teknis \\
\hline $\begin{array}{l}\text { 1. Mempergunakan } \\
\text { keterkaitan diantara } \\
\text { ide-ide matematika } \\
\text { pada materi geometri }\end{array}$ & $\begin{array}{l}\text { 1.1 Penerapan koneksi antara fakta, konsep dan } \\
\text { prinsip matematika untuk permasalahan yang } \\
\text { akan diselesaikan pada materi geometri. } \\
\text { 1.2 Mencari koneksi antar prinsip matematika yang } \\
\text { satu dengan yang lain untuk menyelesaikan } \\
\text { masalah pada materi geometri. } \\
\text { 1.3 Menggunakan hubungan prinsip matematika } \\
\text { satu dengan yang lainnya untuk prinsip atau } \\
\text { formula baru yang diperlukan untuk }\end{array}$ \\
\hline
\end{tabular}

Copyright () 2020

Buana Matematika :

Jurnal Ilmiah Matematika dan Pendidikan Matematika 
Indikator Teknis

menyelesaikan masalah pada materi geometri.

2. Mengaplikasikan ideide matematika dalam kehidupan sehari-hari pada materi geometri.

2.1 Mengidentifikasi prinsip, fakta dan konsep dari konteks diluar matematika pada materi geometri.

2.2 Menggunakan koneksi konsep dengan prosedur dan operasi hitung untuk menyelesaikan masalah atau konteks diluar matematika pada materi geometri.

Sumber: Romli (2018)

Littauer mengembangkan teori Hipocrates-Galenus. Littauer menjelaskan mengenai sifat kepribadian koleris, sanguinis, melankolis, dan plegmatis (Fitria \& Siswono, 2014). Littauer mengungkapkan ciri masing-masing tipe kepribadian yaitu tipe kepribadian sanguinis yang popular, kepribadian koleris kuat, kepribadian melankolis yang sempurna dan kepribadian phlegmatis damai (Widodo, 2015). Tipe kepribadian mempunyai karakternya sendiri untuk menggambarkan ide matematis secara lisan atau tulisan (Prasetyo, dkk, 2017). Sifat-sifat dasar dan perasaan masing-masing tipe kepribadian dibedakan berdasarkan Tabel berikut:

Tabel 2. Teori Kepribadian Sanguinis, Korelis, Melankolis, dan Plegmatis

\begin{tabular}{ll}
\hline \multicolumn{1}{c}{ Kepribadian } & \multicolumn{1}{c}{ Sifat-Sifat } \\
\hline Melankolis & Kurang percaya diri, sedih, pemurung dan pesimistis \\
& $\begin{array}{l}\text { Sifat lain: berhati-hati, konsekuen, tertekan dengan masa lalu, sulit } \\
\text { menyesuaikan diri dan suka menepati janji. }\end{array}$ \\
\hline Sanguinis & Optimis, periang dan percaya diri \\
& Sifat lain: dapat menyesuaikan diri, baik hati, tidak stabil, tidak serius, \\
& kurang dapat dipercaya dan kurang konsekuen \\
\hline Koleris & Beraksi negatif dan agresif, kurang puas \\
& Sifat lain: Emosional, provokasi, egois, tidak sabaran, tidak toresan, \\
& kurang humor. \\
\hline Plegmatis & Tenang, netral, stabil dan pendiam \\
& Sifat lain: merasa cukup puas, acuh, tidak mudah terharu, lambat, \\
& sangat hemat, tertib dan pasif. \\
\hline
\end{tabular}

Sumber: (Nurihsan \& Yusuf, 2008)

\section{Metode}

Jenis penelitian yang digunakan adalah penelitian deskriptif kualitatif dengan bentuk studi kasus. Penelitian ini mengeksplorasi koneksi matematika setiap siswa dengan tipe kepribadian siswa masing-masing. Subjek pada penelitian yaitu siswa kelas X SMK Negeri 2 Tulungagung Copyright $@ 2020$

\section{Buana Matematika :}

Jurnal Ilmiah Matematika dan Pendidikan Matematika 
sebanyak 35 siswa (30 laki-laki dan 5 perempuan). Pemilihan subjek penelitian menggunakan angket tipe kepribadian diadopsi dari angket Florence Littaeur dari buku "Personality Plus". Terdapat 40 pernyataan dalam angket tipe kepribadian yang meliputi hal umum dari sifat kepribadian. Angket digunakan untuk mengelompokkan siswa menjadi 4 tipe kepribadian. Instrumen penelitian ini adalah peneliti sendiri sebagai instrumen utama, angket tipe kepribadian, soal tes koneksi matematika, dan instrumen pedoman wawancara sebagai instrumen pendukung. Berikut ini adalah gambar instrumen soal tes koneksi matematika pada materi bangun ruang.

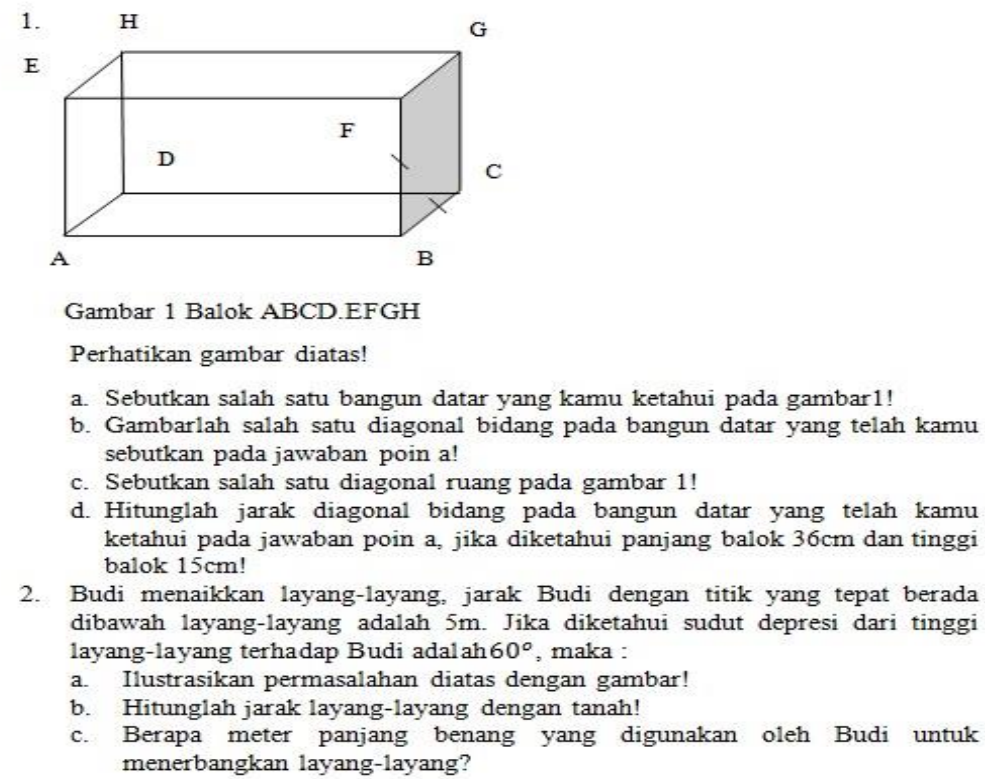

Gambar 1. Instrumen Soal

Adapun dalam pengumpulan data: pertama, memberikan angket tipe kepribadian untuk mengelompokkan tipe kepribadian masing-masing siswa. Kedua, peneliti memberikan soal tes pada seluruh siswa lalu mengelompokkan skor koneksi tertinggi sampai terendah sesuai tipe kepribadian masing-masing siswa. Peneliti mengambil 4 subjek berdasarkan skor tertinggi pada setiap tipe kepribadian. Ketiga, peneliti melakukan wawancara terhadap 4 subjek untuk mencari informasi lebih banyak mengenai koneksi matematis dan jawaban tes koneksi matematika.

Dalam pengelolaan data menggunakan teknik analisis data yang digunakan pada model Sugiyono (2015) yang terdiri dari tiga tahap yaitu: penyajian

Copyright (C) 2020

\section{Buana Matematika :}

Jurnal Ilmiah Matematika dan Pendidikan Matematika 
data, reduksi data, dan penarikan kesimpulan. Adapun penggunaan teknik tringulasi digunakan dalam pengecekan keabsahan data.

\section{Hasil dan Pembahasan}

Angket dibagikan kepada seluruh siswa. Setelah angket selesai diberikan kemudian peneliti menganalisis dan mengelompokkan hasil angket berdasarkan tipe kepribadian. Hasil angket masing-masing tipe kepribadian dapat diamati pada tabel berikut:

Tabel 3.Hasil Angket Tipe Kepribadian

\begin{tabular}{cc}
\hline Tipe Kepribadian & Jumlah \\
\hline Sanguinis & 9 \\
\hline Koleris & 10 \\
\hline Melankolis & 4 \\
\hline Plegmatis & 12 \\
\hline Jumlah & $\mathbf{3 5}$ \\
\hline
\end{tabular}

Tahap selanjutnya yaitu memberikan tes koneksi matematika siswa. Diperoleh hasil skor koneksi matematika dari yang tertinggi sampai terendah bedasarkan tipe kepribadian. Setiap tipe kepribadian diambil 1 subjek nilai tertinggi dari masing-masing tipe kepribadian, sehingga total subjek untuk diwawancarai ada 4 siswa. Daftar subjek yang terpilih dapat diamati pada tabel berikut:

Tabel 4. Subjek yang Terpilih

\begin{tabular}{cc}
\hline Subjek & Tipe Kepribadian \\
\hline MIN & Sanguinis \\
MM & Koleris \\
TAL & Melankolis \\
MRF & Plegmatis \\
\hline
\end{tabular}

Peneliti menganalisis kemampuan koneksi matematika siswa melalui tes tertulis serta membandingkan dengan hasil tes wawancara untuk memperkuat keabsahannya. Berikut analisis subjek koneksi matematika ditinjau dari masing-masing tipe kepribadian. 


\section{a. Analisis kemampuan koneksi matematika tipe kepribadian sanguinis Subjek MIN}
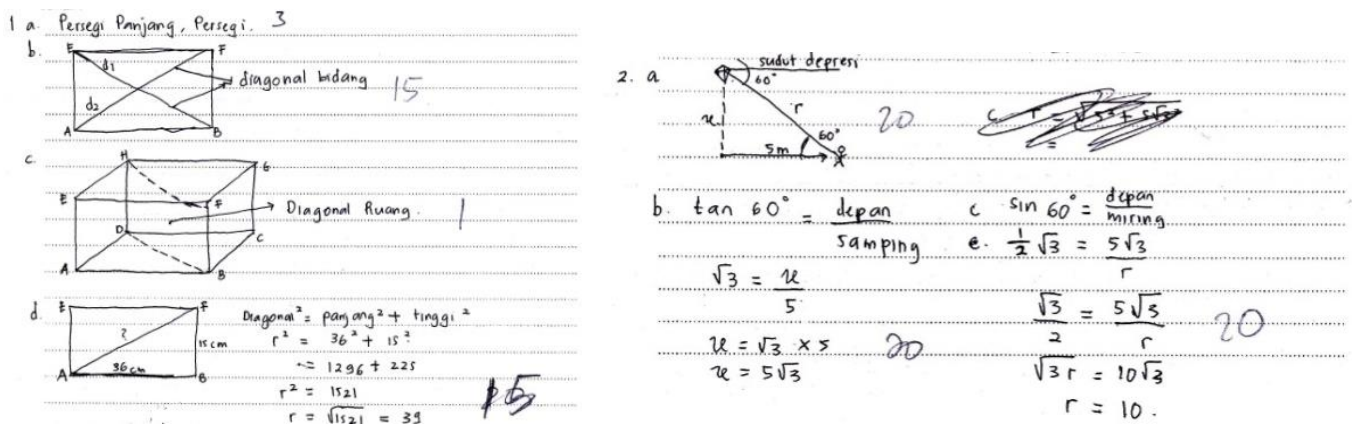

Gambar 2 . Jawaban Soal 1 \& 2 Subjek MIN

Berdasarkan hasil lembar jawaban, subjek MIN mampu memahami dan mengerjakan soal dengan tepat, benar, runtut, dan mudah dipahami. Hasil jawaban soal 1a memenuhi indikator koneksi 1.1 yaitu subjek dapat menyebutkan bangun datar yang ada pada bangun ruang walaupun tidak menyebutkan nama bangun datar yang dipilih. Subjek memenuhi indikator soal nomor $1 \mathrm{~b}$ yaitu dapat menggambarkan diagonal bidang yang ada pada bangun ruang. Pada soal 1c subjek memenuhi indikator 1.2 yaitu subjek mampu mengerjakan bagian yang terbentuk dari diagoanal bidang sisi atas dan sisi bawah balok. Jawaban soal 1d subjek memenuhi indikator 1.3 yaitu dapat menentukan jarak diagonal bidang pada bangun ruang yang hanya diketahui panjang dan tinggi balok dengan menggunakan rumus phytagoras pada segitiga.

Berdasarkan wawancara jawaban soal 1 subjek memenuhi indikator 1.1 yaitu subjek dapat menjelaskan hubungan bangun datar dengan bangun ruang. Subjek memenuhi indikator 1.2 yaitu dapat menjawab dengan benar diagonal yang ditanyakan pada soal. Subjek juga memenuhi indikator 1.3 yaitu subjek yakin dan mengerti cara mencari diagonal yang ditanyakan pada soal menggunakan phytagoras. Soal 2a subjek sudah memenuhi indikator 2.1 yaitu subjek dapat mengilustrasikan permasalahan yang ada pada soal menjadi gambar matematika. Pada Soal $2 b$ dan $2 c$ subjek memenuhi indikator 2.2 yaitu subjek dapat menghitung ketinggian layanglayang menggunakan rumus trigonometri dan pada soal 2c subjek mampu menghitung panjang benang yang digunakan jika diketahui salah satu sudut dan jaraknya menggunakan rumus trigonometri. Berdasarkan hasil jawaban soal subjek mampu mengerjakan soal nomor 2 dengan benar sesuai dengan rumus sehingga memenuhi indikator 2.1 dan 2.2. Berdasarkan hasil

Copyright $@ 2020$

\section{Buana Matematika :}

Jurnal Ilmiah Matematika dan Pendidikan Matematika 
wawancara subjek MIN dapat menyebutkan dengan jelas hubungan permasalahan yang ada terhadap matematika. Subjek MIN juga memenuhi indikator 2.2 yaitu subjek mampu menjawab pertanyaan dengan benar yaitu dapat menunjukkan cara yang digunakan untuk menyelesaikan masalah pada soal. Dari jawaban soal 1 dan 2 subjek MIN memenuhi indikator 1.1, $1.2,1.3,2.1$, dan 2.2 .

\section{b. Analisis kemampuan koneksi matematika tipe kepribadian korelis Subjek MM}
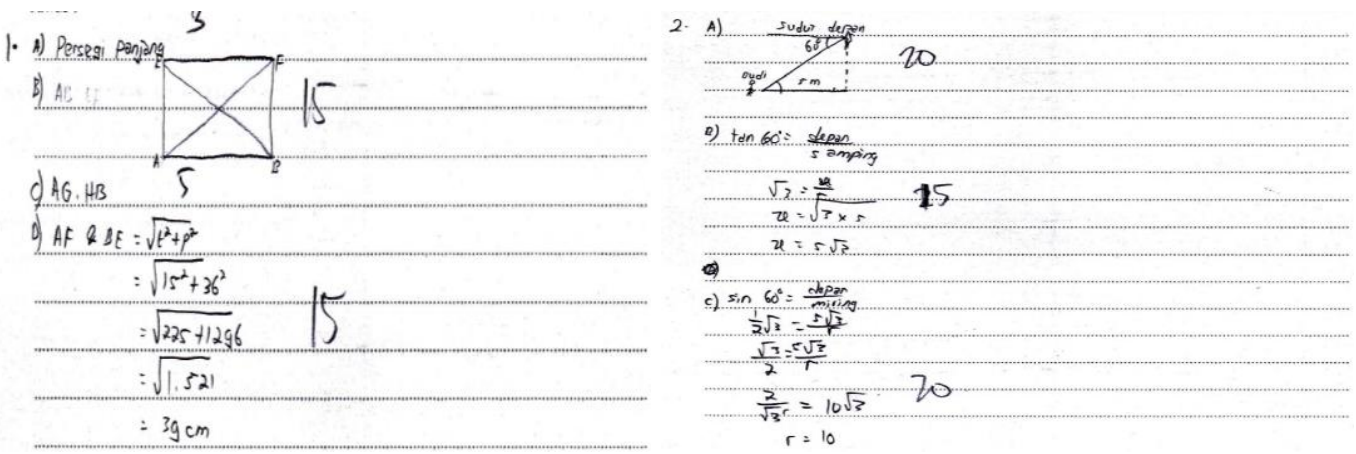

Gambar 3. Lembar Jawaban Soal No. 1 \& 2 Subjek MM

Berdasarkan hasil lembar jawaban, Subjek MM menyelesaikan soal dengan benar, runtut, dan mudah dipahami. Hasil jawaban subjek pada soal 1a sudah memenuhi indikator 1.1 yaitu subjek mampu menyebutkan salah satu bangun datar yang ada pada bangun ruang meskipun tidak menyebutkan nama bangun ruang persegi panjang yang telah disebutkan. Subjek memenuhi indikator 1.2 yaitu menemukan keterkaitan antar prinsip matematika yang satu dengan prinsip yang lain untuk menyelesaikan masalah. Hal ini dapat dilihat dari jawaban subjek pada soal $2 \mathrm{~b}$ yang dapat menggambarkan diagonal bidang yaitu diagonal persegi panjang. Pada soal 2c subjek mampu menyebutkan diagonal ruang balok tersebut. Jawaban subjek pada soal nomor $1 \mathrm{~d}$ memenuhi indikator 1.3 yaitu menggunakan hubungan prinsip satu dengan yang lainnya untuk prinsip atau formula baru yang diperlukan untuk menyelesaikan masalah. Hal ini dapat dilihat dari jawaban subjek yang dapat menjawab dengan tepat berdasarkan rumus dan hal yang diketahui, subjek MM mampu menjawab dengan tepat dan benar untuk menghitung diagonal persegi panjang yang hanya diketahui panjang dan tinggi dari balok.

Berdasarkan wawancara subjek MM mampu memenuhi indikator 2.1 akan tetapi subjek MM kurang memenuhi indikator 2.2 yaitu tidak bisa

Copyright $@ 2020$

\section{Buana Matematika :}

Jurnal Ilmiah Matematika dan Pendidikan Matematika 
menjelaskan cara trigonometri yang telah disebutkan. Sifat kepribadian koleris subjek MM yaitu merasa tidak puas dengan jawaban yang dikerjakan dan memiliki inisiatif untuk berusaha mengerjakan soal sendiri.

\section{c. Analisis kemampuan koneksi matematika tipe kepribadian melankolis Subjek TAL}

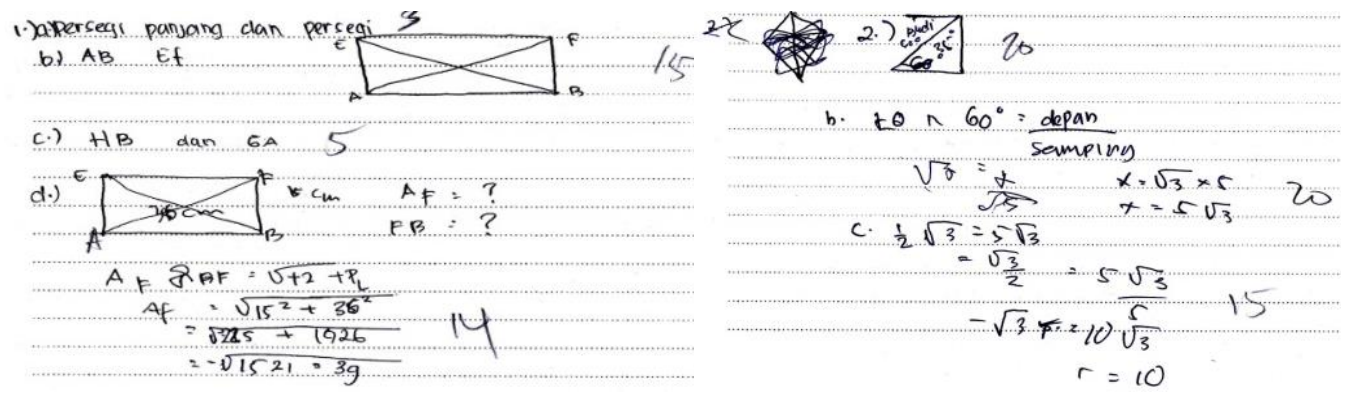

Gambar 4. Lembar Jawaban TAL Soal Nomor 1 \& 2

Subjek TAL sudah memenuhi indikator 1.1 yaitu menggunakan hubungan antara fakta, konsep, prinsip matematika pada masalah yang akan diselesaikan, dapat dilihat pada jawaban subjek TAL nomor 1a dimana subjek TAL menjawab dua sekaligus bangun datar yang ada pada bangun ruang yaitu persegi panjang dan persegi, walaupun subjek tidak menuliskan nama salah satu bangun datar yang sudah disebutkan. Pada indikator 1.2 yaitu menemukan keterkaitan antar prinsip matematika yang satu dengan prinsip yang lain untuk menyelesaikan masalah, dapat dilihat dengan hasil jawaban pada nomor $2 \mathrm{~b}$ bahwa subjek dapat menggambarkan diagonal persegi panjang yang ada pada balok. Pada nomor 2c subjek dapat menyebutkan dua sekaligus diagonal ruang pada balok yaitu HB dan GA. Subjek TAL memenuhi indikator 1.3 yaitu jawaban pada nomor $1 \mathrm{~d}$ menjawab dengan benar meskipun untuk penulisan rumus Phytagoras yang digunakan subjek TAL kurang jelas.

Berdasarkan wawancara subjek TAL memenuhi indikator 1.1 yaitu dapat menyebutkan dan menjawab bangun datar yang ada pada bangun ruang. Subjek TAL juga memenuhi indikator 1.2 yaitu dapat menunjukan diagonal pada bangun yang telah disebutkan sebelumnya. Subjek juga memenuhi indikator 1.3 yaitu mampu menunjukkan cara yang digunakan untuk menyelesaikan masalah. Sifat kepribadian melankolis subjek adalah kurang percaya diri, hal ini dapat dilihat ketika menjawab saat diwawancara raguragu seperti menyebutkan kata "sepertinya" yang menunjukkan keraguan. Pada soal nomor 1 subjek TAL memenuhi indikator 1.1, 1.2 dan 1.3 .

Copyright (C) 2020

\section{Buana Matematika :}

Jurnal Ilmiah Matematika dan Pendidikan Matematika 
Subjek TAL memenuhi indikator 2.1 dan juga memenuhi indikator 2.2 yaitu pada nomor $2 \mathrm{~b}$ subjek dapat mengitung ketinggian layang-layang dengan tepat sesuai rumus trigonometri. Nomor 2c juga memenuhi indikator tersebut, hal ini dibuktikan bahwa subjek dapat menghitung panjang benang. Pada soal nomor 2 subjek memenuhi indikator 2.1 dan indikator 2.2. Berdasarkan wawancara subjek mampu menjelaskan hubungan permasalahan tersebut dengan matematika, hal ini memenuhi indikator 2.1, akan tetapi kurang memenuhi indikator 2.2. Berdasarkan sifat kepribadian melankolis subjek memiliki sifat kurang percaya diri. Subjek TAL memenuhi indikator 2.1 dan kurang memenuhi indikator 2.2.

Dari hasil tes dan wawancara tersebut maka dapat disimpulkan bahwa subjek dapat memenuhi indikator yaitu mengidentifikasi fakta, konsep, prinsip matematika dari konteks diluar matematika dan kurang memenuhi indikator yaitu menggunakan keterkaitan konsep dengan prosedur dan operasi hitung untuk menyelesaikan masalah atau konteks diluar matematika. Hal ini terlihat pada saat wawancara subjek TAL tidak dapat menjelaskan cara menyelesaikan masalah yang ada menggunakan trigonometri sesuai dengan hasil tes yang telah dikerjakan.

\section{d. Analisis kemampuan koneksi matematika tipe kepribadian plegmatis Subjek MRF}

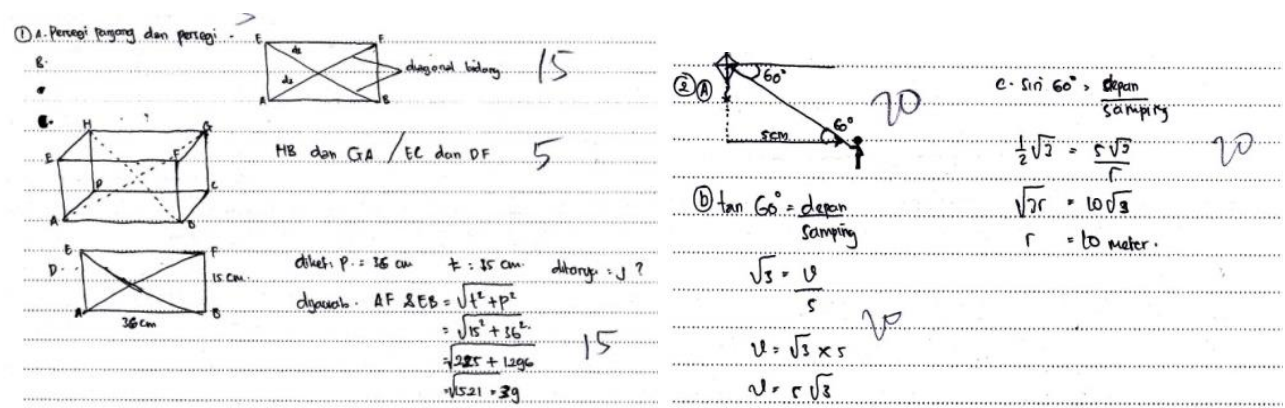

Gambar 5. Lembar Jawaban MRF Soal Nomor 1 \& 2

Subjek MRF memenuhi indikator 1.1, indikator 1.2 dan memenuhi indikator 1.3. Pada indikator 1.1 yaitu menggunakan hubungan antara fakta, konsep, prinsip matematika pada masalah yang akan diselesaikan. Hal tersebut dapat ditunjukan melalui hasil lembar jawaban pada nomor 1a subjek MRF dapat menyebutkan salah satu bangun datar yaitu persegi panjang yang ada pada bangun ruang balok tetapi tidak menuliskan nama dari bangun datar persegi panjang yang telah disebutkan. Pada indikator 1.2 yaitu menemukan keterkaitan antar prinsip matematika yang satu dengan prinsip yang lain

Copyright (C) 2020

\section{Buana Matematika :}

Jurnal Ilmiah Matematika dan Pendidikan Matematika 
untuk menyelesaikan masalah. Pada jawaban subjek MRF pada nomor $1 \mathrm{~b}$ subjek dapat menggambarkan dengan jelas dan tepat diagonal persegi panjang yang ditanyakan pada soal. Pada indikator 1.3 yaitu menggunakan prinsip matematika satu dengan yang lainnya untuk prinsip atau formula baru yang diperlukan untuk menyelesaikan masalah. Subjek MRF dapat memenuhi indikator tersebut dibuktikan dengan hasil jawaban pada soal nomor 1d subjek MRF dapat menentukan jarak diagonal yang ditanyakan pada soal dengan tepat dan rinci dengan menggunakan rumus phytagoras. Pada soal No.2 subjek MRF memenuhi indikator 1.2 yaitu mengidentifikasi fakta, konsep, prinsip matematika dari konteks diluar matematika. Subjek MRF juga memenuhi indikator 2.2 yaitu menggunakan keterkaitan konsep dengan prosedur dan operasi hitung untuk menyelesaikan masalah atau konteks diluar matematika.

Berdasarkan wawancara soal no.1 subjek MRF dapat menjawab secara terperinci dan lengkap. Sehingga subjek MRF sudah memenuhi 3 indikator antara lain indikator 1.1, 1.2 dan 1.3. Berdasarkan sifat kepribadian plegmatis subjek MRF memiliki sifat yang teratur dan tenang hal yaitu pada saat wawancara subjek MRF menjawab pertanyaan dan menjelaskan dengan rinci dan urut. Berdasarkan wawancara soal no. 2 Subjek MRF memenuhi indikator 2.1 dan indikator 2.2, yaitu dapat menujukkan dan menjelaskan permasalahan pada soal. Subjek mampu menunjukkan keterkaitan menggunakan konsep lain yaitu menggunakan rumus trigonometri dan tahu dalam menggunakannya untuk menyelesaikan masalah konteks diluar matematika. Subjek dapat menjelaskan secara tepat semua permasalahan yang ada pada nomor 2 dengan runtut. Berdasarkan sifat kepribadian plegmatis subjek MRF memiliki sifat yang teratur dan tenang hal ini terlihat pada saat wawancara subjek MRF menjawab pertanyaan dan menjelaskan dengan rinci dan urut.

\section{Pembahasan}

Penelitian ini membahas tentang kemampuan koneksi matematika siswa ditinjau dari tipe kepribadian sanguinis, korelis, melankolis, dan plegmatis. Dalam penelitian ini menggunakan 3 cara pengambilan data yaitu angket tipe kepribadian, soal tes koneksi matematika, dan wawancara. Dari hasil analisis data yang telah dilakukan dapat ditemukan beberapa temuan penelitian. Berikut ini pembahasan dari hasil penelitian untuk masingmasing tipe kepribadian:

Copyright (C) 2020

Buana Matematika :

Jurnal Ilmiah Matematika dan Pendidikan Matematika 


\section{Kemampuan koneksi matematika siswa ditinjau dari tipe kepribadian sanguinis}

Berdasarkan hasil tes dan wawancara siswa sanguinis mampu menyelesaikan soal dengan benar sesuai dengan indikator koneksi matematika. Siswa sanguinis mampu menghubungkan fakta, konsep, prinsip pada masalah yang akan diselesaikan, mampu menemukan keterkaitan antar prinsip matematika yang satu dengan yang lain untuk menyelesaikan masalah, dan mampu menggunakan hubungan prinsip matematika yang satu dengan prinsip atau formula baru yang diperlukan untuk menyelesaikan masalah. Siswa sanguinis dapat menyelesaikan soal dengan benar sesuai dengan indikator yaitu mengidentifikasi fakta, konsep, prinsip matematika dari konteks diluar matematika, menggunakan keterkaitan konsep dengan prosedur dan operasi hitung untuk menyelesaikan masalah atau konteks diluar matematika.

Siswa sanguinis memiliki sifat optimis dan percaya diri dalam menjelaskan hubungan permasalahan terhadap matematika dan keterkaitan konsep dengan prosedur serta operasi hitung untuk menyelesaikan masalah atau konteks diluar matematika, hal ini sejalan dengan Yusuf \& Nurihsan (2018) yang menyatakan bahwa kepribadian sanguinis memiliki sifat optimis dan percaya diri .

\section{Kemampuan koneksi matematika siswa ditinjau dari tipe kepribadian} koleris

Berdasarkan hasil tes dan wawancara siswa yang mempunyai tipe kepribadian koleris mampu menyelesaikan soal dengan benar sesuai dengan indikator koneksi matematika. Siswa dengan tipe kerpibadian koleris mampu menghubungkan fakta, konsep, prinsip pada masalah yang akan diselesaikan, mampu menemukan keterkaitan antar prinsip matematika satu dengan yang lain untuk menyelesaikan masalah dan mampu menggunakan hubungan prinsip matematika satu dengan yang lainnya untuk prinsip atau formula baru yang diperlukan dalam menyelesaikan masalah.

Siswa koleris pada soal mampu mengindentifikasi fakta, konsep, prinsip matematika dari konteks diluar matematika tetapi kurang mampu menggunakan keterkaitan konsep dengan prosedur dan operasi hitung untuk menyelesaikan masalah atau konteks diluar matematika. Siswa koleris memiliki sifat merasa kurang puas dengan jawaban yang telah Copyright $\odot 2020$

\section{Buana Matematika :}

Jurnal Ilmiah Matematika dan Pendidikan Matematika 
dikerjakan dan memiliki banyak usaha (inisiatif) untuk berusaha mengerjakan soal sendiri. Hal ini sejalan dengan kepribadian menurut Yusuf \& Nurihsan (2018) bahwa kepribadian korelis memiliki sifat merasa kurang puas dan banyak inisiatif. Hasil penelitian ini sependapat juga dengan Purnaningsih \& Siswono (2014) dimana siswa koleris memiliki kemampuan yang kuat serta tegas, sehingga mampu menyelesaikan permasalahan dengan pemikirannya sendiri dan tidak terpengaruh dengan orang lain disekitarnya.

\section{Kemampuan koneksi matematika siswa ditinjau dari tipe kepribadian} melankolis

Berdasarkan hasil tes dan wawancara siswa dengan tipe kepribadian melankolis mampu memenuhi indikator kemampuan koneksi matematika yaitu menggunakan hubungan antar fakta, konsep, prinsip matematika pada masalah yang akan diselesaikan, mampu menemukan keterkaitan antar prinsip matematika satu dengan prinsip matematika lain untuk menyelesaikan masalah dan menggunakan hubungan prinsip matematika yang satu dengan lainnya untuk prinsip dan formula baru dalam menyelesaikan masalah. Siswa mampu mengidentifikasi fakta, konsep, prinsip matematika dari konteks diluar matematika tetapi kurang dapat menggunakan keterkaitan konsep dengan prosedur dan operasi hitung untuk menyelesaikan masalah atau konteks diluar matematika.

Siswa melankolis memiliki sifat kurang percaya diri dan pesimis sehingga mempengaruhi kemampuan koneksi matematika. Sifat pesimis membuat siswa tersebut tidak mau berusaha untuk menjawab apa yang ditanyakan dan cenderung mengatakan tidak bisa sebelum berusaha menjawab soal. Siswa melankolis meniliki sifat pesimis dan kurang percaya diri dalam menjawab soal hal ini sejalan dengan kepribadian menurut Yusuf \& Nurihsan (2018) yang menyebutkan kepribadian melankolis memiliki sifat pesimis dan kurang percaya diri.

4. Kemampuan koneksi matematika siswa ditinjau dari tipe kepribadian Plegmatis

Berdasarkan hasil tes dan wawancara siswa plegmatis mampu menyelesaikan soal dengan benar sesuai dengan indikator koneksi matematika. Siswa plegmatis mampu menghubungkan fakta, konsep, prinsip pada masalah yang akan diselesaikan, mampu menemukan

Copyright (c) 2020

Buana Matematika :

Jurnal Ilmiah Matematika dan Pendidikan Matematika 
keterkaitan antar prinsip matematika yang satu dengan yang lain untuk menyelesaikan masalah, dan mampu menggunakan hubungan prinsip matematika yang satu dengan prinsip atau formula baru yang diperlukan untuk menyelesaikan masalah. Siswa plegmatis juga dapat menyelesaikan soal dengan benar yaitu mengidentifikasi fakta, konsep, prinsip matematika dari konteks diluar matematika, dan menggunakan keterkaitan konsep dengan prosedur dan operasi hitung untuk menyelesaikan masalah atau konteks diluar matematika. Siswa plegmatis memiliki sifat teratur, tenang yaitu dapat menjelaskan dengan rinci dan runtut keterkaitan menggunakan konsep lain dan tahu dalam menggunakannya untuk menyelesaikan masalah diluar matematika, hal ini sejalan dengan kepribadian menurut Yusuf \& Nurihsan (2018) kepribadian plegmatis memiliki sifat tertib dan teratur. Mayasari, dkk (2019) juga berpendapat bahwa kepribadian plegmatis dapat menyelesaikan soal dengan runtut dan teratur serta memakan waktu yang lama dalam menyelesaikan masalah yang diberikan.

\section{Simpulan}

Berdasarkan rumusan permasalahan maka dapat disimpulkan bahwa setiap tipe kepribadian memiliki kemampuan koneksi yang berbeda. Tipe kepribadian sanguinis dan plegmatis mampu memenuhi semua indikator koneksi matematika yaitu indikator 1-5 sedangkan tipe kepribadian korelis dan melankolis mampu memenuhi 4 indikator yaitu indikator 1-4.

Berdasarkan hasil dan kesimpulan, saran dari peneliti adalah sebagai berikut: siswa tipe kepribadian sanguinis yang memiliki sifat optimis dan percaya diri agar tetap meningkatkan sifat optimis dan percaya diri tersebut sehingga dapat meningkatkan koneksi matematika. Tipe kepribadian koleris untuk tetap mempertahankan sifat kurang puas dan banyak usaha, saat sifat kurang puas muncul, maka akan muncul usaha dari siswa cara untuk menyelesaikan soal. Tipe kepribadian melankolis yang memiliki sifat pesimis dan rasa kurang percaya diri sebaiknya mengurangi atau meminimalisir sifat tersebut karena dapat menghambat koneksi matematika. Siswa tipe kepribadian plegmatis agar mempertahankan sifat tertib atau teratur dalam menyelesaikan soal secara runtut dan rinci. Bagi peneliti selanjutnya dapat mendeskripsikan kemampuan koneksi matematika siswa ditinjau dari tipe kepribadian lainya. 


\section{Daftar Pustaka}

Azis, N. A. (2018). Profil Keterampilan Berpikir Kreatif Siswa dalam Memecahkan Masalah Matematika Ditinjau dari Kepribadian. Jurnal Matematika dan Pembelajaran, 6(2), 143.

Fitria, C., \& Siswono, TEY. (2014). Profil Keterampilan Berpikir Kreatif Siswa dalam Memecahkan Masalah Matematika Ditinjau dari Tipe Kepribadian (Sanguinis, Koleris, Melankolis, dan Phlegmatis). MATHEdunesa Jurnal Ilmiah Pendidikan Matematika, 3(3), 23-32.

Hamidah, N., Susanto, \& Yudianto, E. (2018). Kecerdasan Visual Spasial Siswa Ditinjau dari Tipe Kepribadian Hippocrates-Galenus. Saintifika, 20(2), I-IO.

Hartanti, E. H. (2016). Hubungan Kesulitan Belajar Matematika Terhadap Kemampuan Koneksi Matematika Pada Siswa SMK Kartika 1 Surabaya. Buana Matematika: Jurnal Ilmiah Matematika Dan Pendidikan Matematika, 6(2:), 31-36.

Khamidah, K., \& Suherman. (2016). Proses Berpikir Matematis Siswa dalam Menyelesaikan Masalah Matematika Ditinjau dari Tipe Kepribadian Keirsey. Jurnal Pendidikan Matematika, 7(2), 231-248.

Kumalasari, A., Prihadini, R. O., \& Putri, E. (2013). Kesulitan Belajar Matematika Siswa Ditinjau dari Segi Kemampuan Koneksi Matematika. Seminar Nasional Matematika Dan Pendidikan Matematika, November, MP-714.

Latipah, E. D. P., \& Afriansyah, E. A. (2018). Analisis Kemampuan Koneksi Matematis Siswa Menggunakan Pendekatan Pembelajaran CTL dan RME. Jurnal Matematika, 17(1), 1-12.

Mayasari, D., Utomo, D. P., \& Cholily, Y. M. (2019). Analisis Metakognisi Siswa Dalam Memecahkan Masalah Matematika Ditinjau dari Tipe Kepribadian Hipocrates. Jurnal Kajian Pembelajaran Matematika, 3(1), 3439.

Nurihsan, J., \& Yusuf, S. (2008). Teori Kepribadian. Bandung: Remaja Rosdakarya.

Copyright (C) 2020

Buana Matematika :

Jurnal Ilmiah Matematika dan Pendidikan Matematika 
Pauji, H. M. (2018). Analisis Kemampuan Koneksi Matematik Siswa MTS ditinjau dari Self Regulated Learning. Jurnal Pembelajaran Matematika Inovatif, 1(4), 657-666.

Pitriyani, P., Fitrianna, A. Y., Malinda, P., \& Hajar, M. S. (2018). Analisis Kemampuan Koneksi Matematik Siswa MTS Ditinjau dari Self Confidence. Jurnal Penelitian dan Pembelajaran Matematika, 11(1).

Prasetyo, A., Dwidayati, N. K., \& Junaedi, I. (2017). Students ' s Mathematical Connection Ability and Disposition Reviewed by Keirsey Personality Type through Eliciting Activities Mathematics Learning Model. Unnes Journal of Mathematics Education, 6(2), 190-197.

Purnaningsih, N. E., \& Siswono, T. Y. E. (2014). Profil Metakognisi Siswa Dalam Memecahkan Masalah Matematika Ditinjau Berdasarkan Tipe Kepribadian Koleris Dan Phlegmatis. Jurnal Ilmiah Pendidikan Matematika, 3(3), 152-159.

Romli, M. (2017). Profil Koneksi Matematis Siswa Perempuan Sma Menyelesaikan Masalah Matematika. Jurnal Matematika dan Pendidikan Matematika, 1, 145-157.

Romli, M. (2018). Profil Koneksi Matematis Siswa Perempuan SMA dengan Kemampuan Matematika Tinggi dalam Menyelesaikan Masalah Matematika. MUST: Journal of Mathematics Education, Science and Technology, 1(2), 144

Sholekah, L. M., Anggreini, D., \& Waluyo, A. (2017). Analisis Kesulitan Siswa Dalam Menyelesaikan Soal Matematika Ditinjau dari Koneksi Matematis Materi Limit Fungsi. Wacana Akademika, 1(2), 151-164.

Sugiyono. (2015). Metode Penelitian Kombinasi (Mixed Methods). Bandung: Alfabeta.

Widodo, W. (2015). Perbedaan Tipe Kepribadian terhadap Sikap Belajar Matematika Siswa Kelas X SMA Islam Al-Azhar 5 Cirebon. Sainsmat, IV(1), 67-80. 


\section{Riwayat Hidup Penulis}

\section{Dewi Anggreini}

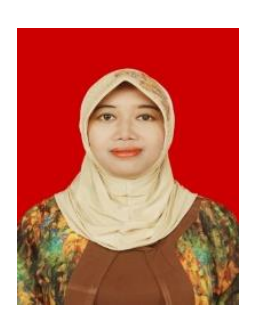

Dewi Anggreini, S.Si, M.Sc. Lahir dan dibesarkan di Yogyakarta, 11 April 1985. Pendidikan S1 diperoleh dari UIN Sunan Kalijaga Yogyakarta (lulus tahun 2008). Pendidikan S2 dari Universitas Gadjah Mada Yogyakarta (lulus tahun 2012). Saat ini bekerja sebagai dosen tetap program Studi Pendidikan Matematika di STKIP PGRI Tulungagung Jawa Timur sejak awal tahun 2013 hingga sekarang. Mata kuliah yang pernah diajar adalah Persamaan Diferensial, Analisis Vektor, Statistik Matematika, Landasan Matematika, dan Komputasi Numerik. Saat ini ia aktif dalam berbagai kegiatan penelitian dan pengabdian kepada masyarakat. Pernah menulis buku Aplikasi Matriks Dalam Menentukan Pertumbuhan Populasi (2017).

\section{Eko Priyojadmiko}

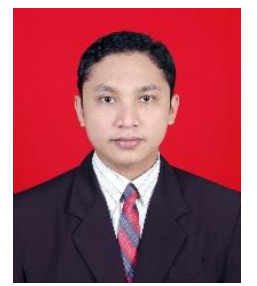

Eko Priyojadmiko, S.E.I., M.E. lahir di Bantul (Yogyakarta) pada tanggal 17 April 1986. Menyelesaikan kuliah dan mendapat gelar sarjana pada Maret 2010. Di tahun 2017 mengikuti program Magister Ekononi di Universitas Islam Negeri Sunan Kalijaga Yogykarta dan lulus dengan predikat Cumlaude ditahun 2019. Tahun 2008, mulai berkarir di salah satu Lembaga Keuangan Mikro Syariah di Yogyakarta. Di tahun 2010, Mulai meniti karirnya pada salah satu Lembaga Perbankan Nasional di Indonesia. Pada 2017, menjadi Branch Manager pada salah satu lembaga pembiayaan swasta di Indonesaia. Berpengalaman menjadi asisten peneliti sejak tahun 2017, pada penelitian hibah kerjasama dengan Kemenristek DIKTI di Jawa Timur hingga saat ini. Buku yang telah dibuat adalah Manajemen Operasi Produksi di tahun 2020.

\section{Dwi Setiana}

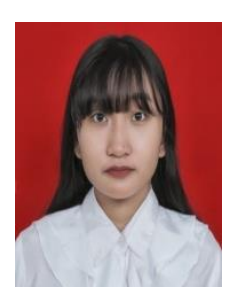

Dwi Setiana, S. P.d. Lahir dan dibesarkan di Tulungagung, 16 September 1996. Riwayat pendidikan lulus SMA pada tahun 2015 dan S1 diperoleh dari STKIP PGRI Tulungagung lulus pada tahun 2019. Aktif dibeberapa organisasi kemahasiswaan. Saat ini bekerja sebagai pengajar di salah satu Sekolah Dasar di Kabupaten Tulungagung.

Copyright (C) 2020

\section{Buana Matematika :}

Jurnal Ilmiah Matematika dan Pendidikan Matematika 